представлен общий анализ мысленно-речевых процессов человека, обеспечивающие восприятие, сохранение новой информации индивидуумом, а также её ментальную обработку и дальнейшее воспроизведение.

В работе представлены точки зрения относительно описанной проблематики ряда известных филологов и психолингвистов: Н. Хомского, Л. С. Выготского, О. М. Леонтьева, О. Р. Лурии, Дж. Андерсона и др. В результате описаного теоретического анализа когнитивных процессов, направленых на восприятие, сохранение, обработку и воспроизведение информации, установлены лексико-предметные соотношения между понятиями языковые знания, лингвистические знания, энциклопедические знания, выводные знания.

В практической части работы задействован ряд психологических и психолингвистических тестовых методик с целью поиска кореляций между психологическими качествами личности и особенностями функционирования её когнитивных процессов, напрямую или опосредствовано звязанных с речевой деятельностью. В результате математической обработки полученных статистических данных удалось определить ряд кореляционных связей между такими психологическими качествами личности, как невротичность, стыдливость, коммуникабельность, познавательный мотив, особенности коммуникативного поведения, структура мотивационной, эмоциональной сфер, и спецификой прохождения когнитивных процессов, связанных с накоплением и формированием языковых знаний с их качественным переходом на уровень языковой компетентности.

Выявленные и описанные в этой работе закономерности и тенденции могут выступить в качестве элементов эмпирической основы при создании новых, личностно ориентированных методик преподавания иностранных языков в будущем. Кроме того, установленные факты могуть быть использованы в построении новых моделей и теорий имитации когнитивных процессов человека.

Ключевые слова: энциклопедические знания, лингвистические знания, выводные знания, врождённые когнитивные структуры, екстериризация, лексикон, языковые знания, языковая компетентность.

Lavrunenko Oleksandr. Functional Correlations Between Lingual Knowledge and Psychological Features of Personality during the Process of Lingual-Thinking Activity. This article represents the theoretical empirical research of human inner cognitive processes, connected with thinking and speech activity. The research unites in its plot the philological and psychological paradigms. In the theoretical part the general view and analysis of human speech-thinking processes is conducted, which provide the perception, keeping of new information by individual, its mental processing and future reproduction.

The author reflected views to the described problematic of the set of famous philologists and psycholinguists: N. Homsky, L. Vygotsky, A. Leontev, A. Luria, J. Anderson and others. Due to the results of the mentioned theoretical analysis of cognitive processes, directed for perception, keeping, processing and reproduction of any type of lingual information the author achieved to define the lexical-subject relations between the notions like lingual knowledge, linguistic knowledge, encyclopedic knowledge and derivational knowledge.

In the practical part of this research the set of psychological and psycholinguistic methodic was applied in order to search the correlations between the psychological features of personality and the peculiarities of its cognitive processes functioning, directly or indirectly connected with the lingual activity.

In the result of the mathematical processing of the gathered statistical data the several functional correlations were found between such psychological human features as neuroticism, shyness, sociability, cognitive motive, peculiarities of communal behavior, motivational and emotional spheres structure and the specifics of course of processes, that are connected with the formation and accumulation of lingual knowledge and its qualitative transition to the level of lingual competence.

The disclosed tendencies and patterns in the mentioned aspect may can act as elements of empirical foundation in the future creation of new personality-oriented methodic of foreign language teaching. Besides, the disclosed facts can have certain use for creation of new models and theories of human cognitive processes.

Key-words: encyclopedic knowledge, linguistic knowledge, derivative knowledge, inborn cognitive structures, exteriorization, lexicon, lingual knowledge, lingual competence.

DOI: https://doi.org/10.32782/2410-0927-2020-13-15

УДК $811.111 ’ 373.21$

Ірина Лесик

\title{
ПРІЗВИСЬКА ЯК ВЕРБАЛЬНА РЕПРЕЗЕНТАЦІЯ ІМІДЖУ ПОЛІТИКА
}

У статті з'ясовано роль прізвиськ у формуванні іміджу політика. Значну увагу зосереджено на виявленні особливостей функціонування прізвиськ у політичній комунікації. Матеріалом дослідження слугували прізвиська американського політичного діяча Джо Байдена, вилучені з американських онлайн-медіа, політичних форумів та блогів. Проаналізовано мотиваційні ознаки, які становлять основу прізвиськ Джо Байдена. Із-поміж аналізованих мовних одиниць високою продуктивністю характеризуються неофіційні іменування політика, мотивувальною базою яких є властивості індивіда, наприклад, розумові та комунікативні здібності, риси характеру, темперамент й особливості поведінки. Вагоме місце посідають прізвиська, які вказують на соціальний статус, політичні погляди та переконання. Порівняно невелику групу становлять неофіційні антропоніми, що умотивовані звичками та

(C) Лесик I., 2020 
вподобаннями. Виявлено, що мовна креативність у царині політичних прізвиськ реалізується за допомогою використання іронії, мовної гри та прецедентних феноменів. Установлено специфіку дискурсивної реалізації прізвиськ як вербальних складників іміджу політика. Доведено, що прізвиська слугують не лише ідентифікації та характеризації особи, а, передаючи інформацію про ставлення комуніканта до об'єкта йменування, підсвідомо діють на створення бажаного іміджу, слугують потужною ідеологічною зброєю.

Ключові слова: прізвисько, антропонім, імідж, мотиваційна ознака, прецедентний феномен.

Вступ. Сучасна лінгвістика демонструє значний інтерес до проблем, пов’язаних із соціальними факторами ідеологічного змісту (ідеологія та пропаганда, ідеологічне осмислення мовних одиниць, лексикон і мовлення політиків тощо) [5]. Увагу лінгвістів усе більше привертають ті чи інші мовні одиниці, які цілеспрямовано використовують політики для формування бажаної громадської думки.

3 огляду на те, що мова успішного політика повинна бути простою, розумною та яскравою, спічрайтери й іміджмейкери дуже прискіпливо ставляться до вибору слова. Фахівці радять добирати такі слова та фрази, які можуть стати незабутніми, свіжими й розважальними одночасно. Ось чому мова політика містить багато виразних слів та фраз, які мають потужний експресивний потенціал. Серед слів наділені надзвичайною силою прагматичного впливу політичні прізвиська або нікнейми. Можна використовувати різні аргументативні засоби й техніки пропаганди, а можна влучно нагородити своїх політичних опонентів прізвиськом і тим самим створити образ ворога, дискредитувати, завдати нещадної критики чи погасити соціальну напруженість.

Останні дослідження неофіційних іменувань осіб зі сфери політики спрямовані на з'ясування лінгвістичного статусу прізвиськ у політичній комунікації, виявленні їхніх функціональних, семантичних та стилістичних особливостей $[3 ; 6 ; 9]$. У фокусі уваги дослідників перебувають також соціальні та культурні характеристики прізвиськ, неофіційні політичні номінації розглядають як віддзеркалення культурних реалій, ціннісних уявлень соціуму, стереотипів щодо політичного лідера країни [8; 11].

Прізвиська $є$ поширеним явищем американської дійсності. Вони зазвичай використовуються в політичному дискурсі для позначення політичних лідерів, особливо президентів США. Коли прізвисько застосовується, замість справжнього імені президента чи політичного діяча, що викликає набір асоціацій щодо характеру чи вчинків політика й виявляє ставлення до нього мовця. Політична сфера спілкування використовує прізвиська як інструмент впливу. Вони слугують засобом маркування, навішування ярликів, створюючи імідж названої особи із боку як опонентів, так і прихильників.

Мета статті - установити функціонально-семантичні особливості прізвиськ політичних діячів в американському політичному дискурсі та з'ясувати комунікативну роль цих мовних одиниць у формуванні іміджу політика. Досягнення поставленої мети вимагає виконання таких дослідницьких завдань: 1) з'ясувати семантичну специфіку й функціональну природу прізвиськ у політичній комунікації; 2) виявити основні мотиваційні ознаки прізвиськ американського політика Джо Байдена 3) дослідити прізвиська як вербальні засоби створення іміджу політика.

Матеріалом дослідження слугували прізвиська американського політичного діяча Джо Байдена, вилучені з американських періодичних онлайн видань, а також соціальної мережі Інтернет.

Методи та методики дослідження. Відповідно до мети та завдань цієї розвідки, застосовано комплексну методику дослідження, де поряд із загальнонауковими методами використано низку спеціальних лінгвістичних методів і прийомів, як-от: метод комунікативнофункціонального аналізу, за допомогою якого виявлено функціональну специфіку прізвиськ у політичному дискурсі; метод структурно-семантичного аналізу - задля з'ясування особливостей семантики неофіційних іменувань у сфері політики.

Результати та дискусії. У сучасній лінгвістиці немає єдиного загальновизнаного визначення, яке б вичерпано окреслило зміст поняття прізвисько. Зазвичай його трактують як «вид антропоніма, додаткову неофіційну назву, дану людині оточенням за визначальними рисами іiі характеру, фізичними ознаками, звичками, походженням» [1, с. 155]. Природа вибору прізвиськового йменування ідентична механізму й факторам вторинної номінації: прізвиська 
утворюються шляхом асоціативно-семантичного відображення властивостей та особливостей об'єкта $[12$, с. 75]. Прізвисько, належачи до класу власних імен, на думку М. Дуйчак, виконує номінативно-ідентифікаційно-диференційну функцію [2, с. 256].

Основну дослідницьку увагу лінгвістів, які звертаються до семантики прізвиськ, спрямовано також на їх дескриптивну функцію, здатності характеризувати індивіда. Дескриптивна функція прізвиськ тісно пов'язана 3 емоційними, оцінними та стилістичними компонентами їхньої семантики. Прізвиська спроможні виражати емоційні переживання людини, його суб'єктивне емоційно-оцінне ставлення до адресата. Прізвиська - оцінні найменування, вони прямо чи непрямо вказують на статус особи в суспільстві та його суспільну оцінку $[10$, с. 8$]$.

Прізвиська політичних діячів можуть різнитися за своїм емоційним забарвленням, варіюватися від злісних й образливих до жартівливих і комічних, що визначається відносинами між адресатом та адресантом, наміром мовця, а також самим соціальним контекстом. Наприклад, деякі політичні прізвиська мають позитивну конотацію, жартівливий і навіть ласкавий відтінок, якщо їх використовують політичні прихильники чи сам політик. Водночас негативний потенціал прізвиськ можуть застосовувати під час характеристики політичні опоненти.

Президентська передвиборча кампанія в США 2020 р. посприяла активізації процесу формування та поширення прізвиськ публічних осіб і, передусім, прізвиськ політиків. Одним із головних учасників кампанії є Дональд Трамп, який відомий своєю манерою вигадувати образливі прізвиська для політичних опонентів, конкурентів з передвиборчої боротьби. Трамп використовує вміння веселити чи шокувати аудиторію своєю вербальною та невербальною поведінкою, збільшуючи власний рейтинг. Прізвиська політичних діячів у цьому плані $\epsilon$ найефективнішими засобами впливу. Політиком, який став мішенню Трампа в президентських перегонах цього року, став представник демократичної партії Джо Байден. Засоби масової комунікації, швидко долучившись до процесу, не просто фіксують і поширюють прізвиськові йменування Джо Байдена, але й цілеспрямовано використовують ті чи інші прізвиська для формування бажаної громадської думки, для підтримки або неприйняття тих чи інших думок та вчинків політика. На тлі «відсутності розвиненого критичного мислення у більшості виборців», прізвиська стають інструментом конструювання іміджу політика, закріплення його образу в масовій свідомості.

Аналіз мовного матеріалу дав підстави виявити основні моделі прізвиськ Джо Байдена залежно від таких мотиваційних ознак, як: характерні властивості, особливості поведінки, соціальний статус та фінансове становище, політичні погляди й переконання, звички.

Прізвиська, які мотивовані характерними властивостями особи, становлять найчисленнішу групу. У цю групу входять такі психологічні властивості, як пам'ять, сенсомоторні реакції, увага, мислення, риси характеру, темперамент.

Трамп регулярно зневажливо називає свого суперника на виборах Sleepy Joe, Slow Joe через появу раніше відеороликів, на яких політик виглядає невиспаним і втомленим та, однак, що, на його думку, 77 річному Байдену бракує життєвих сил й енергії для президентських перегонів і президенства загалом. Biden drives a stake through Trump's «Sleepy Joe» attacks, reminds us what we've missed in a leader [4].

Користувачі соціальних мереж також уживають прізвиська 3 негативним оцінним значенням (Bloodless Joe, Declining Joe Biden), піддаючи насмішці млявість та стриманість у рухах Байдена.

Опоненти демократа, вибравши вік Байдена головним об’єктом нападів, часто звинувачують його в тому, що він постійно плутає поняття, імена й цифри, не може чітко сформулювати свої думки. Це мотивувало появу таких прізвиськ із пейоративною конотацією, як Memory Loss Joe, Imperfect Memory Joe. Байден і сам називає себе gaffe machine («машиною ляпів»).

Дональд Трамп також не упустив можливості поіронізувати над «деменцією» демократа (Dementia Joe), заявивши, що останній «не пам'ятає, що робив вчора» та не впорається 3 обов'язками президента. 
Низку прізвиськ Байдена мотивовано його комунікативними властивостями й умінням вести дебати. Однак ця, здавалося б, позитивна якість виражена в негативно-оцінних прізвиськах із боку його опонентів: Mumblemouth, Muddled Joe Biden, які імплікують те, що йому бракує ораторської майстерності.

У цю групу входять також прізвиська, які містять сему «риси характеру». Колишнього віцепрезидента звинувачують у непостійності щодо прийнятих рішень, необачній брехні й лицемірстві, що викликало появу таких прізвиськ, як Lyin Joe Biden, Ol' Lyin' Joe. Негативний потенціал прізвиськ посилюється пейоративними епітетами (lyin'). Такі неофіційні іменування особи, формуючи в електорату негативне почуття-ставлення, спрямовані на дискредитацію політика, руйнування його позитивного іміджу.

Wimpy Joe Biden - інше розповсюджене прізвисько, у значенні якого міститься натяк на слабкий характер кандидата на президентську посаду, нестачу впевненості та рішучості.

Прихильники поглядів Байдена, акцентуючи увагу на його позитивних властивостях, уживають прізвиська Diamond Joe, Nice Old Joe, Genuine Joe, Меліоративні прізвиськові йменування відіграють важливу роль у формуванні позитивного іміджу політика в масовій свідомості електорату. Передаючи почуття-ставлення захоплення (diamond, nice, genuine), вони водночас викликають позитивний емотивний стан.

Інша група прізвиськ мотивована особливостями поведінки. Обережна поведінка Байдена в умовах пандемії коронавірусу стала підставою для створення цілої серії образливих прізвиськ із боку політичного конкурента, таких як Joe Hiden, Basement Biden.

President Trump taunted his Democratic opponent with a new nickname: "Joe Hiden'.» "Can you believe what's happening!?» Trump tweeted Wednesday, with a link to a Breitbart article. "They give Joe Hiden' the questions, and he reads them an answer!» [7].

Трамп написав прізвище Байден як Hiden (захований або невидимий), найімовірніше, натякаючи на те, що Байден провів значну частину президентської кампанії у своєму будинку в штаті Делавер, намагаючись уникати публічних заходів через загрозу коронавірусної інфекції.

Інша особливість поведінки Байдена полягає в тому, що він любить фізичні контакти. Минулого року вісім жінок стверджували, що він торкався до них неналежним чином, обіймав або цілував. По телебаченню показали кадри, як він, вітаючись із жінками на публіці, наближався й нахилявся до них, немовби нюхаючи їхнє волосся. Така дивна поведінка політика спровокувала появу зневажливих прізвиськ: Creepy Joe, Creepy Uncle Joe (creepy - causing a sensation of repulsion, horror, or fear).

Група прізвиськ, мотиваційною основою яких є соціальний статус особи в суспільстві, фінансове становище, досить численна. До неї можна віднести такі прізвиська, як Upper Class Joe, Millionaire Joe, Wall Street Joe, Goldcard Joe, Big Money Joe, Big Business Joe Biden.

Для пересічних виборців Байден - представник далекої від народу фінансової еліти, вони піддають сумніву його спроможність діяти на користь незаможних громадян, тому вищезгадані прізвиська, які об'єднує сема «гроші», виражають негативну приховану оцінку та відбивають їхнє критичне ставлення до обіцянок політика.

Прізвисько Wall Street Joe актуалізує широковідому екстралінгвістичну інформацію, посилання на історичний центр фінансового кварталу міста Нью-Йорк із його відомою фондовою біржею, тим самим натякаючи на приналежність Байдена до класу фінансових магнатів.

Група прізвиськ, появу яких мотивовано політичними поглядами та переконаннями, є неминучою для політика, оскільки виражає принципи його політичної діяльності, цінності, вірування, політичні ідеали й весь світогляд загалом. До цієї групи можна віднести такі прізвиська, як China-Lovin' Joe Biden, China Joe Biden, Free Trade Joe Biden, Internationalist Joe Biden, Imperialist Joe Biden, Neoconservative Joe, Anti-Communist Joe, Neoliberal Joe. Як бачимо 3 наведених прикладів, прізвиська відображають політичний курс і поведінку Джо Байдена на політичній арені.

Цікавим прикладом нікнейму Джо Байдена з пейоративним оцінним значенням є Herbert Hoover 2020. Експресивний вплив цього прізвиська реалізується завдяки алюзії до фонових знань американців: прізвисько апелює до прецедентного імені та містить натяк на правління 
Гувера, обраного президентом у 1928 р., яке ознаменувалося важкою економічною кризою Великою депресією. Гувер, не зумівши знайти вихід з економічної кризи, утратив репутацію й довів країну до повного банкрутства. Прецедентне ім'я (Herbert Hoover) актуалізує загальновідому екстралінгвістичну інформацію та призводить до створення аналогії з Джо Байденом, якому опоненти закидають нездатність до ефективної економічної політики, що може призвести до економічної рецесії на кшталт Великої депресії за часів Гувера.

Трамп додав нове прізвисько Байдена, яке слугує ефективним мовним прийомом побудови негативного іміджу опонента - Joe Headwind.

«You know what I call him? I call him Joe Headwind,» Trump said in Butler, Pennsylvania, referring to Biden's potential economic policies as a constraint on the on the U.S. recovery [13].

Так уживаючи зневажливі, образливі прізвиська, Трамп дискредитує й деморалізує свого суперника та створює його негативний образ у свідомості електорату. Водночас прізвиська виконують розважальну функцію, викликають посмішку, здивування, що підсилює їх впливовий потенціал і привертає увагу своєю новизною.

Інша група прізвиськ умотивована звичками та вподобаннями політика. Amtrak Joe (Amtrak - американська залізнична компанія, що займається пасажирськими перевезеннями) прізвисько, яке він отримав після того, як щодня їздив поїздом до міста Вашингтон, округ Колумбія, і додому в Делавер протягом 36 років після трагічної втрати дружини й дочки в автокатастрофі. Нейтральне прізвисько, що експлікує звичку Байдена, набуває меліоративного оцінного значення в контексті схвалення його прихильниками того, що він переймається проблемами зміни клімату та заторів на дорогах.

Отже, класифікація прізвиськ за мотиваційними ознаками свідчить про збереження основних тенденцій прізвиськової номінації. Найбільш численними групами $є$ прізвиська на основі характерних властивостей денотата, які експлікують його розумові здібності, риси характеру, темперамент й особливості поведінки. Широко представлені прізвиська, які відображають соціальний статус та політичні погляди.

Потрібно зазначити, що прізвиська Джо Байдена, виступаючи засобом вербалізації іміджу політика, створюють два протилежних образи - 3 позитивним і негативним знаком оцінки, причому прізвиська, що створюють негативний образ, істотно більш численні. Сукупність негативно-оцінних прізвиськ зображає Джо Байдена як представника далекої від народу еліти, брехливого й слабкого політика, у якого спостерігаємо зниження розумових здібностей та розвиток вікової деменції; котрий дозволяє собі речі, які іншим видаються дивними та нетактовними. Позитивний імідж політика репрезентується меліоративними прізвиськами, що представляють Байдена як приємну, доброзичливу, чуйну людину; політика 3 поміркованими поглядами, який переймається проблемами довкілля й думає про процвітання своєї країни.

Факт наявності переважної кількості саме пейоративних прізвиськ, котрі можуть бути схарактеризовані як більш чи менш агресивні, і як образливі, неполіткоректні, абсолютно не прийнятні 3 етичного погляду, пояснюється прагненням опонентів подати політичного конкурента в негативному світлі, використати прізвиська як засіб руйнування позитивного образу. Це досягається завдяки властивості прізвиськ приписувати об'єктам номінації ознаки, які їм насправді не притаманні, маніпулюючи свідомістю електорату, не здатного до критичного мислення.

Висновки. У політичній комунікації прізвиська, основу яких становлять певні реальні чи уявні ознаки, не лише ідентифікують та характеризують особу, а, формуючи певне оцінне ставлення, слугують потужною ідеологічною зброєю, спрямованою на створення бажаного іміджу політика і його закріплення в масовій свідомості.

Функціонування прізвиськ у соціополітичному контексті є нетривалим. Вони швидко 3'являються й зникають, закарбовується в мові лише незначна кількість. Час покаже, які 3 розглянутих нами неофіційних іменувань політика увійдуть в історію та залишаться в мові.

Перспективи дослідження вбачаємо у вивченні інших вербальних засобів створення іміджу політика та виявленні його актуальних лінгвальних маркерів. 


\section{References}

1. Buchko, Dmytro and Tkachova, Natalia. 2012. Slovnyk ukrainskoi onomastychnoi terminolohii. Kharkiv: Ranok-NT.

2. Duichak, M. 1994. "Prizvyska ta yikh motyvatsiia". Problemy suchasnoi areolohii. Kyiv: Nauk. Dumka, 256-259.

3. Gladkova, Anna. 2003. "The semantics of nicknames of the American presidents". Proceedings of the 2002 Conference of the Australian Linguistics Society. URL: http://www.als.asn.au/proceedings/als2002/ Gladkova.pdf.

4. Huppke, Rex. August 21, 2020. "Column: Biden drives a stake through Trump's 'Sleepy Joe' attacks, reminds us what we've missed in a leader". Chicago Tribune. URL: https://www.chicagotribune.com/columns/rexhuppke/ct-biden-trump-democratic-convention-empathy-election-huppke-20200821oqx6foj3evfhreejmahcvtifwm-story.html.

5. Kudryavtseva, L. 2011. "Massmediynyi politicheskiy diskurs Ukrainy: osobennosti "poslemaydannogo" perioda". Yazyk $i$ diskurs sredstv massovoy informatsii $v$ XXI veke: kollektivnaya monografiya. Moskva: Akademicheskiy proekt, 30-43.

6. Lebedieva N., Butenko O. 2010. "Funktsionalni, semantychni ta stylistychni osoblyvosti politychnykh nikneimiv u suchasnii anhliiskii movi”. Naukovyi visnyk Volynskoho natsionalnoho universytetu imeni Lesi Ukrainky 9: 139-142.

7. Phillips, Morgan. September 2, 2020. “Trump tries out new nickname: 'Joe Hiden'”. Fox News. URL: https://www.foxnews.com/politics/trump-new-nickname-joe-hiden.

8. Prikhodko, I. G. 2015. "Prozvishchnye nominatsii kak marker korrektnosti i tsennostnykh predstavleniy sotsiuma”. Movni i kontseptualni kartyny svitu 2: 105-117.

9. Saplin, Yu. 2007. "Sotsiolinhvistychni funktsii ukrainskykh neofitsiinykh politychnykh nominatsii". Styl i tekst: naukovyi zbirnyk Instytutu zhurnalistyky KNU im. T. H. Shevchenka. URL: http://journlib.univ.kiev.ua/ index.php?act $=$ article $\&$ article $=2137$.

10. Superanskaya, Aleksandra. 1990. Imya - cherez veka i strany. Moskva: Nauka.

11. Tsepkova, Anna. 2013. "Nicknames and culture: Analysing anthroponymic nicknames, reflecting cultural realia”. Numele și numirea. Actele Conferinței Internaționale de Onomastică: Onomastica din spațiul public actual,831-838.

12. Van Ness, R. V. 2008. "Ispolzovanie vtorichnoy nominatsii pri sozdanii prozvishchnykh naimenovaniy". Vestnik YuurGU 16: 74-77.

13. Wingrove, Josh and Sink, Justin. October 31, 2020. "Trump Tries New Biden Nickname in Pennsylvania: Campaign Update”. Bloomberg. https://www.bloomberg.com/news/articles/2020-10-31/trump-still-weighinghis-election-night-plans-campaign-update

Лесик Ирина. Прозвища как вербальная репрезентация имиджа политика. В статье рассматривается роль прозвищных именований в формировании имиджа политика. Значительное внимание уделяется выявлению особенностей функционирования прозвищ в политической коммуникации. Материалом исследования послужили прозвища американского политического деятеля Джо Байдена, взятые из американских онлайн-медиа, политических форумов и блогов. Проанализированы мотивационные признаки, которые составляют основу прозвищ Джо Байдена. Среди анализированных языковых единиц высокой производительностью отличаются неофициальные именования политика, мотивационной базой для которых послужили характерные свойства индивида, такие как умственные и коммуникативные способности, черты характера, темперамент и особенности поведения. Важное место занимают прозвища, указывающие на социальный статус, политические взгляды и убеждения. Сравнительно небольшую группу составляют неофициальные антропонимы, которые мотивированы привычками и предпочтениями. Выявлено, что языковая креативность в области политических прозвищных именований реализуется посредством использования иронии, языковой игры и прецедентных феноменов. Установлена специфика дискурсивной реализации прозвищ как вербальных составляющих имиджа политика. Доказано, что прозвища служат не только идентификации и характеризации лица, а, передавая информацию об отношении коммуниканта к объекту именования, подсознательно влияют на создание желаемого имиджа, служат мощным идеологическим оружием.

Ключевые слова: прозвище, антропоним, имидж, мотивационный признак, прецедентность.

Lesyk Iryna. Nicknames as a Verbal Representation of the Image of a Politician. The article examines the role of nicknames in the formation of the image of a politician. Much attention is focused on identifying the peculiarities of the functioning of nicknames in political communication. The research material was the nicknames of the American politician Joe Biden, taken from American online media, political forums and blogs. The motivational features that form the basis of Joe Biden's nicknames are analysed. Among the analysed linguistic units, highly productive informal names of the politician have the motivation based on the characteristic features of the individual, such as mental and communicative abilities, character traits, temperament and behaviour. Nicknames that indicate social status, political views and beliefs occupy an important place as well. A relatively small group consists of informal anthroponyms motivated by habits and preferences. It has been revealed that linguistic creativity in the field of political nicknames is manifested through the use of irony, language play and precedent phenomena. The specificity of the discursive realization of nicknames as verbal components of the politician's image has been established. It has been proved that nicknames serve not only to identify and characterize a person, but by conveying information about the attitude of the communicant to the object of naming, subconsciously influence the creation of the desired image, serve as a powerful ideological weapon.

Key words: nickname, anthroponym, image, motivational feature, precedent. 